\title{
Application of Fluorescence in situ hybridization-Flow cytometry (FISH-FCM) technique to detect and quantify Vibrio cholerae populations from different geographic regions
}

\author{
Lidita Khandeparker ${ }^{1, *}$, Dattesh V. Desai', Arga Chandrashekar Anil', S. S. Sawant ${ }^{1},{ }^{1}$. Venkat', Kaushal Mapari', \\ Zuliza Jolkifli2, Noorizan Abd. Karim², Hikmah Thoha ${ }^{3}$, Hadiyanto Hadiyanto ${ }^{3}$, Soukaseum Dalasane ${ }^{4}$, \\ Kongngeun Chounlamountry ${ }^{5}$, Myint Myint Khaing ${ }^{6}$, Jenelle Clarisse Dungca ${ }^{7}$, Rhodora Azanza ${ }^{7}$, Chin Sing Lim ${ }^{8}$, \\ Koh Siang $\operatorname{Tan}^{8}$, Sumana Kajonwattanakul ${ }^{9}$, Ratchanee Phuttapreecha ${ }^{10}$, and Hoang Mai Le ${ }^{11}$
}

${ }^{1}$ CSIR-National Institute of Oceanography, Goa, India

${ }^{2}$ Fisheries Ecology and Oceanography Section, Department of Fisheries, Ministry of Industry and Primary Resources, Brunei Darussalam ${ }^{3}$ Research Center for Oceanography, Indonesian Institute of Sciences, Jakarta, Indonesia

${ }^{4}$ Port and Navigation Division, Department of Waterways, Ministry of Public Works and Transport, Vientiane, Lao PDR

${ }^{5}$ Lao National Mekong Committee Secretariat, Ministry of Natural Resources and Environment, Khounboulom Road, Vientiane, Lao PDR

${ }^{6}$ Remote Sensing Department, Mandalay Technological University, Mandalay, Myanmar

${ }^{7}$ The Marine Science Institute, College of Science, University of the Philippines, Diliman, Quezon City, The Philippines

${ }^{8}$ St John's Island National Marine Laboratory, Tropical Marine Science Institute, National University of Singapore, Singapore ${ }^{9}$ Department of Marine and Coastal Resources, Phuket Marine Biological Center (Bangkok Office), Bangkok, Thailand

${ }^{10}$ Department of Marine and Coastal Resources, Marine and Coastal Resources Research Center (Southern Part), Songkhla, Thailand

${ }^{11}$ Northern Center for Integrated Coastal Management and Planning, Vietnam Administration of Seas and Islands, Ha Noi, Vietnam

*Corresponding author: klidita@nio.org

KEYWORDS

Fluorescence in situ hybridization (FISH)

Flow cytometry (FCM)

Bacteria

FISH-FCM

Vibrio cholerae

Bioinvasion
ABSTRACT Rapid and species-specific detection, and quantification of pathogenic bacteria are fundamental for monitoring and assessment of the risk they pose to any ecosystem. The study employed Vibrio cholerae, a human pathogen responsible for the life-threatening diarrhoeal disease, cholera and one among the most unwanted from marine bioinvasion point of view. The present study coupled fluorescence in situ hybridization (FISH) technique, a powerful tool in molecular phylogenetic discrimination, with flow cytometry (FCM), a technique used for rapid and accurate quantification of both viable but non-cultivable and non-viable microorganisms. The FISH-FCM technique was used for the first time to quantify V. cholerae (includes cultivable and noncultivable) from different geographic regions of Southeast Asia (Brunei, Indonesia, Lao PDR, Myanmar, Philippines, Singapore, Thailand, Vietnam) and India (Goa, west coast of India). The data acquired from the analyses provides a snapshot view of the total bacterial abundance with special reference to $V$. cholerae. As the method developed, it was evaluated with bacterial samples collected from different sites in Southeast Asia and India, and the application of this technique to different geographical regions appears feasible. Considering that the continuous growth of the shipping industry and ballast water as one of the primary vectors responsible for the global transport of pathogenic microorganisms, the risk they present needs immediate attention. This technique will be useful in the quick and accurate detection of specific pathogens. It may also provide significant insights to quarantine measures for Ballast Water Management.

(c) The Author(s) 2018. This article is distributed under a Creative Commons Attribution-ShareAlike 4.0 International license.

\section{INTRODUCTION}

Ships move over $90 \%$ of the world's commodities and are thus responsible for the global transfer of approximately 10 billion tons of ballast water (BW), which is used to maintain their stability. Ballast tanks hold different nonindigenous vertebrates, invertebrates, plants, microscopic algae, bacteria, and viruses (Williams et al. 1988; Carlton and Geller 1993; Smith et al. 1996; Ruiz et al. 2000; Drake et al. 2007; Mimura et al. 2005). When an organism is introduced into an alien environment, a process termed as 'bioinvasion', it can either change the biodiversity of the food web or can have a direct impact on the society and human health by affecting water quality and fisheries (Anil et al. 2002; Sun et al. 2010). Hence, ballast water is recognized as one of the important vectors of bioinvasion that threaten naturally evolved biodiversity, the consequences of which are increasingly being realized (Anil et al. 2002; Hewitt and Campbell 2010).

Microorganisms are highly abundant in the aquatic environments and can withstand a wide range of environmental conditions owing to which are introduced into alien environments in larger numbers than other organisms (Roszak et al. 1984; Hallegraeff and Bolch 1992). Pathogenic bacteria, viruses, protists, and microalgae can have devastating effects on the ecosystem and economic resources. Among pathogenic bacteria, the most extensively studied bacterium in ballast water is Vibrio cholerae, 
which is responsible for cholera, an acute diarrheal disease characterized by rapid and severe dehydration and in extreme cases even death of the infected persons (Finkelstein 1996). Although more than 200 O-antigen serogroups of V. cholerae are known so far, only two serogroups, O1 and O139, have been found to cause cholera epidemics (Sack et al. 2003). It is a known fact that ballast water is one of the major vectors leading to global transport of toxigenic V. cholerae O1, O139 (Ruiz et al. 2000), owing to which V. cholerae is placed as one of the 'Ten Most Unwanted' in the Global Ballast Water Management Programme (GloBallast 2002).

The culturable pathogenic bacteria as specified in D2 guidelines for performance of ballast water treatment technologies (2004) are routinely estimated by the plating methods using specific media (Khandeparker et al. 2015). However, they are time-consuming, and the plating method cannot account for the cells that are in a dormant state. It has been demonstrated that viable but non-culturable bacteria are active in metabolism and can still be infectious. Lyon (2001) developed a Taq-Man PCR assay for quantitative detection of $\mathrm{V}$. cholerae in pure cultures, oysters, and synthetic seawater. The probe was designed from the non-classical hemolysin (hlyA) sequence of V. cholerae strains. Recently, Emami et al. (2012) evaluated a rapid and cost-effective matrix-assisted laser desorption ionization-time of flight mass spectrometry (MALDI-TOF MS) method for monitoring culturable bacteria in ballast water. Several marine bacterial species were characterized using this method. However, only those bacteria which can be cultured can be identified, and only $0.001-0.1 \%$ of marine bacteria are culturable (Oren 2004).

Flow cytometry (FCM) is an advanced technique being extensively used for counting microorganisms, wherein cells are usually labeled with fluorescent tags which allow them to be electronically identified while passing through a beam of laser light and can detect both non-viable and viable cells. Recently, flow cytometry is being extensively used for counting microorganisms (Davey et al. 1999; Ivanov 2000; Shvalov et al. 2000; Khandeparker et al. 2017a) and assessing their viability (López-Amorós et al. 1997). It has also been used to evaluate the abundance of selected bacterial species in ballast water samples (Joachimsthal et al. 2004).

The use of Fluorescence In-Situ Hybridization (FISH) to identify specific bacteria within environmental samples has become a powerful tool that helps in molecular phylogenetic discrimination.

Flow cytometry combined with FISH is currently a popular method of enumerating specific cells in environmental samples (Not et al. 2002; Czechowska et al. 2008). Direct quantification methods without the need to enrich and culture yield accurate and quick estimates of taxonspecific densities in water bodies (Huq et al. 2012) and allow quantification of both cultivable and non-cultivable (VBNC) bacteria. However, to the best of our knowledge FISH-FCM coupling study does not exist for the quantification of V. cholerae.

In the present study, FISH-FCM was used to quantify V. cholerae from Brunei Darussalam, India, Indonesia, Lao PDR, Myanmar, Philippines, Singapore, Thailand, and Vietnam along with the total bacterial count (TBC). Ruiz et al. (2000) have reported that bacteria associated with plankton are the principal contributors of pathogenic bacteria introduced to the Chesapeake Bay. The genus Vibrio is wide spread in the coastal water, autochthonous in the water of estuarine regions, where the bacteria survive in association with plankton, as well as in biofilms. The port areas are potential sites for ballasting/deballasting, and presence of both pathogenic and non-pathogenic strains are reported in the ballast water of cargo ships. The snap shot observations carried out in the present study would provide the distribution of $\mathrm{V}$. cholerae in different geographic regions.

\section{MATERIALS AND METHODS}

\subsection{Sample collection and preservation}

Water samples were collected by the participating members in the project in and around the port environment in Brunei Darussalam, India, Indonesia, Lao PDR, Myanmar, The Philippines, Singapore, Thailand, and Vietnam for the quantification of Total Bacterial Count (TBC) and V. cholerae. Aliquots of the samples $(9 \mathrm{~mL})$ were fixed using a $4 \%$ paraformaldehyde solution (final concentration 1\%) by incubation at $4^{\circ} \mathrm{C}$ overnight, followed by storage at $-20^{\circ} \mathrm{C}$ until analysis. These were then transferred to CSIR-National Institute of Oceanography, Dona Paula, Goa, India for further analysis in the laboratory using FCM.

Water samples from Brunei Darussalam were collected at Muara Port $\left(5^{\circ} 1.809^{\prime} \mathrm{N}, 115^{\circ} 4.850^{\prime} \mathrm{E}\right)$, which is the main gateway for foreign goods coming into the country, as well as for the export of local produce.

The samples from India were collected from Zuari and Mandovi estuaries in Goa as well as the port environments. Dona Paula $\left(15^{\circ} 25^{\prime} 16.9^{\prime \prime} \mathrm{N}, 73^{\circ} 47^{\prime} 36.9^{\prime \prime} \mathrm{E}\right)$ - bay station situated at the mouth of the estuary (Goa, India 1), Cortalim $\left(15^{\circ} 24^{\prime} 32.0^{\prime} \mathrm{N}, 73^{\circ} 54^{\prime} 50.2^{\prime} \mathrm{E}\right)$ - lower middle estuary (Goa, India 2), Chicalim $\left(15^{\circ} 24^{\prime} 10.92^{\prime \prime N}, 73^{\circ} 51^{\prime} 8.55^{\prime \prime} \mathrm{E}\right)$ highly influenced by anthropogenic activity and shipping industry (Goa, India 3) and Siridao $\left(15^{\circ} 25^{\prime} 41.89 " \mathrm{~N}\right.$, $\left.73^{\circ} 52^{\prime} 38.84 " \mathrm{E}\right)$ - receives inputs from the mangrove area (Goa, India 4) were sampled in the Zuari estuary. Whereas, Campal $\left(15^{\circ} 29^{\prime} 36.26^{\prime \prime} \mathrm{N}, 73^{\circ} 48^{\prime} 42.08^{\prime \prime} \mathrm{E}\right)$ - situated at the mouth of the estuary was sampled in the Mandovi estuary (Goa, India 5). Both these estuaries are situated on the west coast of India. Samples from New Mangalore port (Mangalore, India), which is an enclosed sea port located in Panambur, Mangalore, Karnataka on the west coast of India $\left(12^{\circ} 55^{\prime} \mathrm{N}, 78^{\circ} 48^{\prime} \mathrm{E}\right)$ and Chennai Port (Chennai, India), which is a major sea-port situated on the east coast of India $\left(13^{\circ} 06^{\prime} \mathrm{N}, 80^{\circ} 18^{\prime} \mathrm{E}\right)$ were also collected.

Water samples from Indonesia were collected from the international port of Tanjung Priok in Jakarta Bay $\left(6^{\circ} 5^{\prime} 56.47^{\prime \prime S}, 106^{\circ} 53^{\prime} 15.88 " \mathrm{E}\right)$. Water characteristics around the bay are not only affected by monsoons (Schoemar and Yanagi 2001) but also highly influenced by a large amount of anthropogenic waste coming from thirteen rivers (Siregar et al. 2016).

Water samples from Lao PDR were collected from Vientiane Port $\left(17^{\circ} 56^{\prime} 47.23^{\prime \prime} \mathrm{N}, 102^{\circ} 36^{\prime} 55.38^{\prime \prime} \mathrm{E}\right)$ along the Mekong River. In Myanmar, water samples were obtained from a jetty at Yangon Port $\left(16^{\circ} 45.708^{\prime} \mathrm{N}, 9^{\circ} 9.657^{\prime} \mathrm{E}\right)$, which is located some $20 \mathrm{~km}$ upstream from the mouth of the Yangon River.

One of the major ports in the Philippines is South Harbour in Manila, which is located in the northeast shoulder of Manila Bay $\left(14^{\circ} 36.2^{\prime} \mathrm{N}, 120^{\circ} 58.0^{\prime} \mathrm{E}\right)$ and about 45 km from Pasig River. From 2000 to 2012, it accommodated over 6500 foreign and domestic vessels (Philippine Ports Authority 2015). Water samples were collected rom six stations (Station 1: Pier 15, Station 2: Pier 13, Sta- 
tion 3: Pier 9, Station 4: Pier 5; Station 5: Engineering Island; and Station 6) along the pier in July 2012.

Water samples from Singapore were collected from a recreational marina (Republic of Singapore Yacht Club, RSYC) situated in the southwest coast $\left(1^{\circ} 17^{\prime} 36^{\prime \prime} \mathrm{N}\right.$, $103^{\circ} 45^{\prime} 37^{\prime \prime} \mathrm{E}$ ) of Singapore Island. This marina is situated in close proximity to a major container shipping terminal as well as monsoonal canals and drainages.

Water samples were collected from Songkhla Port $\left(7^{\circ} 13.826^{\prime} \mathrm{N}, 100^{\circ} 34.3^{\prime} \mathrm{E}\right)$ in Thailand. In Vietnam, water samples were collected from Haiphong Port (2050'57.4" N, 106²5’11.85” E).

\subsection{Flow cytometric analysis for determining the Total Bacterial Count (TBC)}

For the analyses of the total bacterial count, $1 \mathrm{~mL}$ of fixed samples were used. Initially, the water samples were passed through BD cell strainer cap (Cat no: 352235) to remove larger particles. The samples were then stained with DAPI (Sigma) at $1 \mu \mathrm{g} / \mathrm{mL}$ final concentration (Troussellier et al., 1995) and incubated for $30 \mathrm{~min}$ in the dark at room temperature. Subsequently, samples were analyzed using a BD FACSAria ${ }^{\mathrm{TM}}$ II (BD Biosciences) flow cytometer equipped with a nuclear UV laser $375 \mathrm{~nm}$ which can differentiate blue fluorescence excited by UV light. Emitted light was collected through following filter sets 488/10 band pass (BP) for right angle light scatter (SSC) and $450 / 20$ band pass (BP) for blue fluorescence. Fluorescent beads $(1 \mu \mathrm{m}$, Polysciences) were used as internal standards. Gating was done against SSC versus blue fluorescence. Flow cytometry data was processed using BD FACS Diva software. Total Bacterial Count (TBC) is expressed as cells/mL.

\subsection{Fluorescent In-Situ Hybridization (FISH) coupled with FCM for specific detection of $V$. cholerae}

The TaqMan probe developed by Lyon (2001), designed from the non-classical hemolysin (hlyA) sequence of $\mathrm{V}$. cholerae cultivable strains was used. In the present study, we validated this probe for quantifying both cultivable and non-cultivable population using FISH. The probe was labeled with Alexa 488 and synthesized by (Sigma-Aldrich Co. USA). Alexa 488-labeled probe, 5'-[A488] TCAACCGATGCGATTGCCCAAGA) was used for the detection of V. cholerae. For standardization, the fixed samples were hy- bridized with the probe using hybridization buffer $(20 \mathrm{mM}$ Tris $\mathrm{HCl}, 0.9 \mathrm{M} \mathrm{NaCl}$ and $0.1 \% \mathrm{SDS}$, final concentration).

The working concentration of the probe was 50 $\mathrm{ng} / \mu \mathrm{L}$ in sterilized water (final concentration, $5 \mathrm{ng} / \mu \mathrm{L}$ ). The hybridization reactions were performed using different melting temperatures $\left(40-55^{\circ} \mathrm{C}\right)$ and the formamide concentrations ( 0 to $30 \%$ ). The probe showed good results at $46^{\circ} \mathrm{C}$ using formamide concentration of $30 \%$.

The labeled V. cholerae were visualized under an epifluorescence microscope (Olympus IX 73, Olympus, Japan) by using a FITC filter ( $\lambda$ exc: $490 \mathrm{~nm}$; $\lambda$ em: $525 \mathrm{~nm}$ ) following which they were enumerated using flow cytometry in the present study. These samples were analyzed using a BD FACSAriaTM II (BD Biosciences) flow cytometer equipped with a nuclear blue laser $488 \mathrm{~nm}$ which can differentiate green fluorescence excited by a blue laser. Emitted light was collected through following filter sets $488 / 10$ band pass (BP) for right angle light scatter (SSC) and $530 / 30$ band pass (BP) for green fluorescence. Fluorescent beads ( $1 \mu \mathrm{m}$, polysciences) were used for calibration of the above parameters as internal standards. Gating was done against SSC versus green fluorescence. Flow cytometry data were processed using BD FACSDIVA software. The V. cholerae abundance is expressed as cells/mL.

\section{RESULTS AND DISCUSSION}

Flow cytometric analysis of bacteria using dual staining clearly separated green fluorescing Alexa 488-conjugated probe specific V. cholerae from blue fluorescing DAPI stained TBC (Figure 1). The TBC ranged from $2.70 \times 10^{3} \pm$ 469 (Philippines) to $2.21 \times 10^{7} \pm 4.8 \times 10^{5}$ (Myanmar). A representation of the variation in the TBC in studied locations is provided in Figure 2. TBC was highest at Myanmar followed by Vietnam and least at the Philippines.

The data from India is sourced from a tropical estuarine environment (Zuari and Mandovi estuaries in Goa) and the port environments. Dona Paula, Cortalim, Chicalim and Siridao were sampled in the Zuari estuary, and Campal was sampled in the Mandovi estuary. Previously, the dominance of cultivable Vibrio, Alteromonas, Aeromonas, Enterobacter, Marinobacter, and Exiquinobacterium have been reported in the Zuari estuary (Khandeparker et al. 2011; Fernandes et al. 2014; Khandeparker et al. 2015). The Dona Paula station in Zuari estuary showed a high abundance of cultivable V.
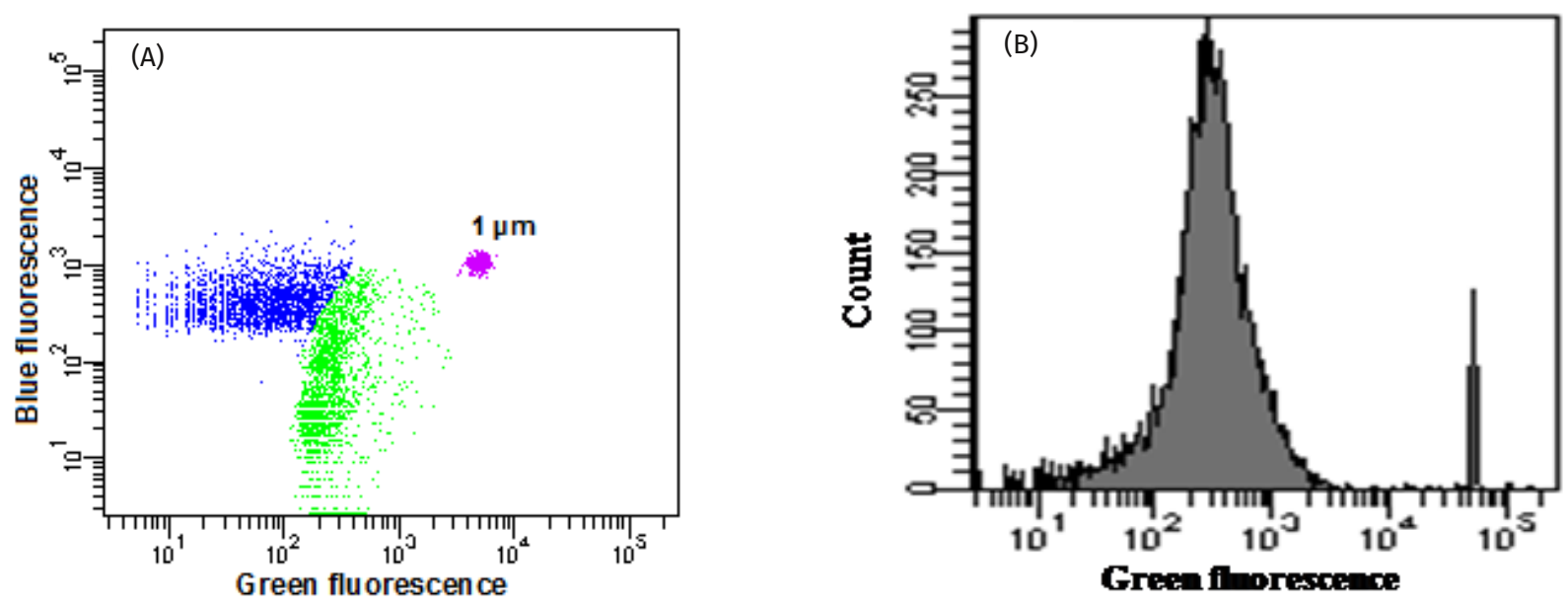

Figure 1. (A) Two-parameter flow cytometric dot-plot of DAPI stained bacteria (Blue fluorescence) giving an account of Total Bacterial Count (TBC) and Vibrio cholerae population specifically attached to Alexa 488-conjugated probe (Green fluorescence). Gating is done against green versus blue fluorescence. Fluorescent beads ( $1 \mu \mathrm{m}$, Polysciences) were used for calibration of the above parameters as internal standards. (B) Alexa 488 fluorescence (Green fluorescence) histogram plot analysis of $V$. cholerae specifically detected on binding to Alexa 488-conjugated probe. 

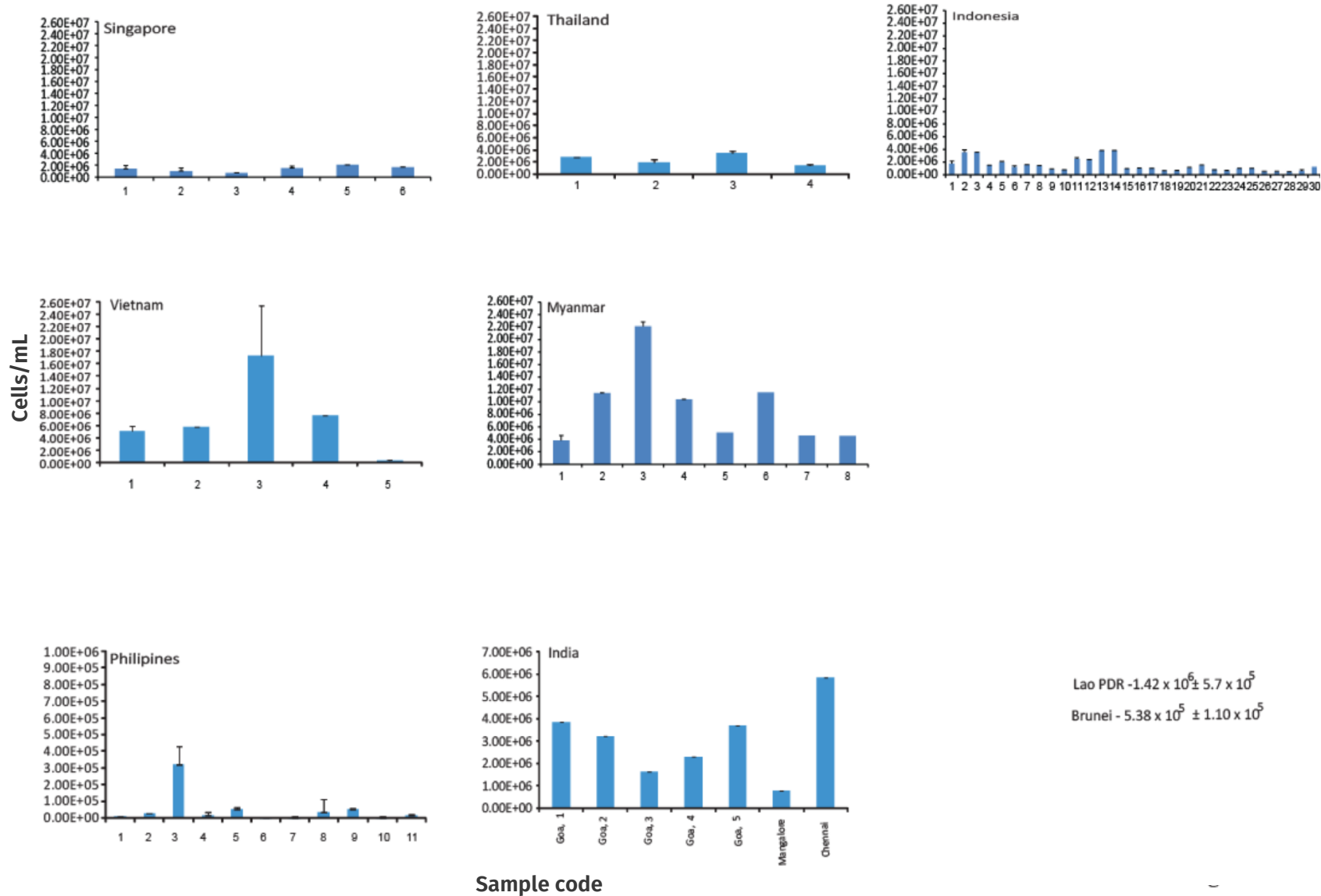

Lao PDR $-1.42 \times 10^{6} \pm 5.7 \times 10^{5}$

Brunei - $5.38 \times 10^{5} \pm 1.10 \times 10^{5}$

Figure 2. Spatial and regional variation of Total Bacterial Count (TBC) in India and ASEAN countries using flow cytometry (FCM). Sample locations are provided in the Materials and Methods section.

cholerae in the monsoon season (Khandeparker et al. 2015). For the present study, the samples were collected during the monsoon season and accounts for total V. cholerae (cultivable and non-cultivable). The V. cholerae population was high in Dona Paula, Cortalim, and Chicalim. Chicalim is an anthropogenically influenced area in the Zuari estuary. Recently, Khandeparker et al. (2017b) used Next-Generation Sequencing (NGS) approach using Ion Torrent PGM ${ }^{\mathrm{TM}}$ to elucidate the microbial community structure of MandoviZuari estuarine sediment. The results indicated that Chicalim in Zuari estuary was dominated by Proteobacteria, mainly Gammaproteobacteria, which comprises of most of the pathogenic groups such as Enterobacteriaceae,
Pseudomonadaceae, and Vibrionaceae, which are euryhaline and mostly introduced anthropogenically. Association between $\mathrm{V}$. cholerae and chitinous plankton in the marine environment is well known (Huq et al. 1983; Gil et al. 2004). Variations in monsoon (D'Costa et al. 2008) and break period influence the phytoplankton dynamics in this region. A recent study by Khandeparker and Anil (2013) have reported that zooplankton contains high numbers of pathogenic bacteria such as V. cholerae, E. coli, and S. faecalis. It is expected that an increase in phytoplankton production, in turn, would trigger the abundance of zooplankton which feeds on them. V. cholerae preferentially attach to planktonic copepods and are also closely linked

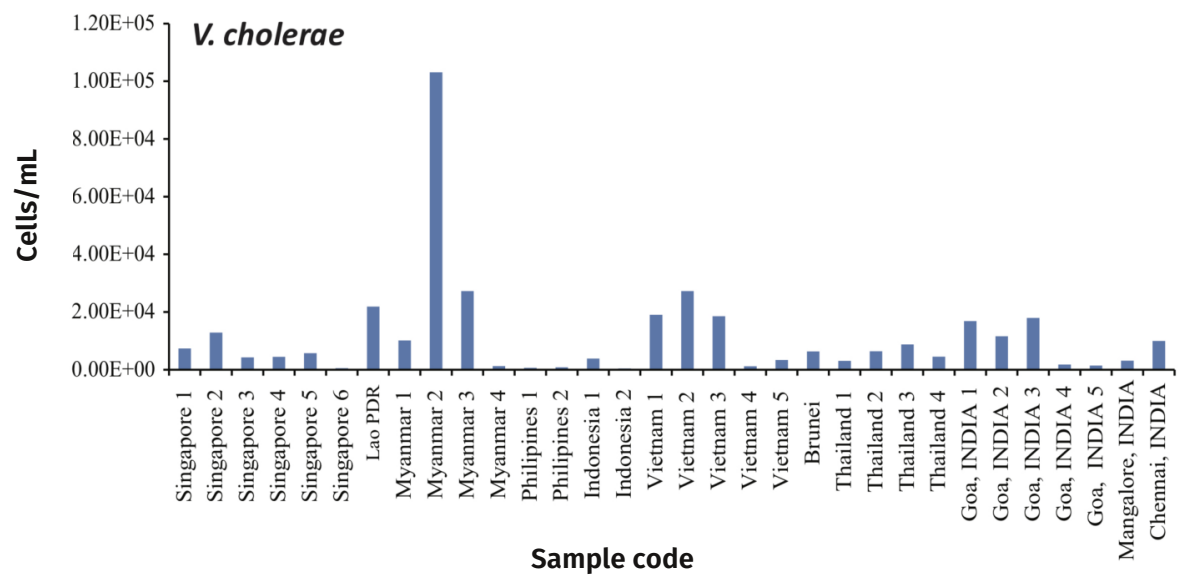

Figure 3. FISH-FCM analyses showing spatial and regional variation of Vibrio cholerae abundance in India and ASEAN countries. Sample locations are provided in the Materials and Methods section. 
with diatoms (Rehnstam-Holm et al. 2010). Previous research has also indicated that nutrients can directly impact algae and zooplankton which may further influence $\mathrm{V}$. cholerae populations (Huq et al. 1996; Mourino-Perez et al. 2003) as plankton, especially zooplankton serves as microhabitat for bacteria (Tang 2005). High numbers of V. cholerae at Dona Paula and Chicalim could also probably be attributed to the abundance of plankton. The abundance of V. cholerae and TBC was low at Singapore; one possible reason could be low phosphate levels in the port region.

Nutrients and suspended particulate matter are important factors in determining the bacterial abundance in a coastal environment (Khandeparker et al. 2017a). Azanza et al. (2018) isolated a total of 93 bacteria from the surface and bottom waters of South Harbour, Manila Bay of Philippines. A total of 64 isolates were representatives from four bacterial phyla: Actinobacteria (22\%), Bacteriodetes (1\%), Firmicutes (12\%), and Proteobacteria (34\%). Three isolates identified were reported as pathogenic bacteria, namely: Gordonia bronchialis, Kytococcus sedentarius, and Microbacterium oleivorans (Azanza et al. 2018). G. bronchialis is a human pathogen associated with pulmonary disease (Tsukamura 1971), K. sedentarius is considered as an opportunistic pathogen that causes valve endocarditis, hemorrhagic pneumonia and pitted keratolysis (Sims et al. 2009) and M. oleivorans is known to cause bacteremia (Kim and Lee 2012).

The data obtained from the analysis of snap shot observations show considerable variations in the V. cholerae in different regions. When compared to other regions, the V. cholerae as well as the total bacterial abundance was low in the Philippines. K. sedentarius is known to produce oligoketides which is a natural antibiotic (Sims et al. 2009). Antibiotics are one class among the many other metabolites produced by bacteria that helps in competition and signaling processes (Khandeparker et al. 2014). The Firmicutes which includes Bacillus spp. were also reasonably high in the Manila Bay, Philippines. However, the abundance of V. cholerae was very low (Figure 3). The presence of Bacillus spp. has been reported to be inhibitory to Vibrio spp. (Sugita et al. 1998; Moriarty 1998). Marine Actinobacteria are known to produce a unique and wide range of antibiotics (Maskey et al. 2003; Li and Qin 2005). The dominance of Actinobacteria and Firmicutes could be responsible for low TBC and V. cholerae in the Philippines and can be attributed to competition as these phyla are known to produce antibiotics and secondary metabolites.

This study validates a FISH-FCM method for the quantification of $\mathrm{V}$. cholerae, and the results serve as baseline data for their abundance, which has implications in bio-invasion in different geographic regions. Earlier studies have revealed that marine pathogens can spread locally much faster (McCallum et al. 2004) than terrestrial ones. These pathogenic bacteria can be devastating on the economic resources and different ecosystems. Taking into consideration the growing shipping industry, it is clear that the risk of global dispersal of aquatic pathogens needs immediate attention and the data so collected will be helpful in developing risk assessment-based decision support system for ballast water management.

\section{ACKNOWLEDGEMENTS}

We are grateful to the Director National Institute of Oceanography, Goa for his support and encouragement. We also thank Mr. Ranjith E and Ms. Sneha Naik from BBD department for their help during this study. This work was supported by Ballast Water Management Programme, India (Ministry of Shipping and DG shipping), CSIR funded Ocean Finder Program and ASEAN-India Cooperation Project entitled "Extent of transfer of alien invasive organisms in South/SE Asia region by shipping". This is an NIO contribution.

\section{REFERENCES}

Anil AC, Venkat K, Sawant SS, Dileepkumar M, Dhargalkar VK, Ramaiah N, Harkantra SN, Ansari ZA. 2002. Marine bioinvasion: Concern for ecology and shipping. Current Science 83(3):214-219.

Azanza RV, Austero NM, Dungca JCR, Caspe FJO, Khandeparker L. 2018. Phytoplankton and bacterial communities in South Harbour, Manila Bay, Philippines. ASEAN Journal on Science and Technology for Development 35(1-2):107-113.

Carlton JT, Geller JB. 1993. Ecological roulette: the global transport of non-indigenous marine organisms. Science 261:78-82.

Czechowska K, Johnson DR, van der Meer JR. 2008. Use of flow cytometric methods for single-cell analysis in environmental microbiology. Current Opinion in Microbiology 11:205-212.

Davey HM, Jones A, Shaw AD, Kell DB. 1999. Variable selection and multivariate methods for the identification of microorganisms by flow cytometry. Cytometry 35(2):162-168.

Drake LA, Doblin MA, Dobbs FC. 2007. Potential microbial bioinvasions via ships' ballast water, sediment, and biofilm. Marine Pollution Bulletin 55(7):333-341.

D'Costa PM, Anil AC, Patil JS, Hegde S, D'Silva MS, Chourasia M. 2008. Dinoflagellates in a mesotrophic, tropical environment influenced by monsoon. Estuarine, Coastal and Shelf Science 77:77-90.

Emami K, Askari V, Ullrich M, Mohinudeen K, Anil AC, Khandeparker L, Burgess JG, Mesbahi E. 2012. Characterization of bacteria in ballast water using MALDI-TOF mass spectrometry. PloS One 7(6):38515.

Fernandes SO, Kirchman DL, Michotey VD, Bonin PC, LokaBharathi PA. 2014. Bacterial diversity in relatively pristine and anthropogenicallyinfluenced mangrove ecosystems (Goa, India). Brazilian Journal of Microbiology 45:1161-1171.

Finkelstein RA. 1996. Cholera, Vibrio cholerae O1 and O139, and other pathogenic Vibrios. In: Baron S, editor. Medical Microbiology. $4^{\text {th }}$ ed. Galveston (TX): University of Texas Medical Branch at Galveston. Chapter 24.

Gil AI, Louis VR, Rivera ING, Lipp E, Huq A, Lanata CF, Taylor DN, Cohen ER, Choopun N, Sack RB, Colwell RR. 2004. Occurrence and distribution of Vibrio cholerae in the coastal environment of Peru. Environmental Microbiology 6:699-706.

GloBallast. 2002. The GEF/UNDP/IMO Global Ballast Water Management Programme (GloBallast). Available from <http://www.globallast.imo.org>

Hallegraeff GM, Bolch CJ. 1992. Transport of diatom and dinoflagellate resting spores in ships' ballast water: implications for plankton biogeography and aquaculture. Journal of Plankton Research 14(8):1067-1084.

Hewitt C, Campbell M. 2010. The relative contribution of vectors to the introduction and translocation of marine invasive species. Australian Department of 
Agriculture Fisheries, and Forestry, Canberra, Australia.

Huq A, Small EB, West PA, Huq MI, Rahman R, Colwell RR. 1983. Ecological relationships between Vibrio cholerae and planktonic crustacean copepods. Applied and Environmental Microbiology 45:275-283.

Huq A, Xu B, Chowdhury MAR, Islam MS, Montilla R, Colwell RR. 1996. A simple filtration method to remove plankton-associated Vibrio cholerae in raw water supplies in developing countries. Applied and Environmental Microbiology 62:2508-2512.

Huq A, Haley BJ, Taviani E, Chen A, Hasan NA, Colwell RR. 2012. Detection, isolation, and identification of $\mathrm{Vi}$ brio cholerae from the environment. Current Protocols in Microbiology; CHAPTER: Unit6A.5. doi:10.1002/9780471729259.mc06a05s26.

Ivanov V. 2000. Monitoring the bacterial neuston. In: Stopa PJ, Bartoszcze MA, editors. Rapid methods for analysis of biological materials in the environment. Netherlands: Springer. p. 67-72.

Joachimsthal EL, Ivanov V, Tay SL, Tay JH. 2004. Bacteriological examination of ballast water in Singapore Harbour by flow cytometry with FISH. Marine Pollution Bulletin 49(4):334-343.

Khandeparker R, Verma P, Deobagkar D. 2011. A novel halotolerant xylanase from marine isolate Bacillus subtilis cho40: gene cloning and sequencing. New Biotechnology 28:814-821.

Khandeparker L, Anil AC. 2013. Association of bacteria with marine invertebrates: implications for ballast water management. EcoHealth 10(3):268-276.

Khandeparker L, D'Costa PM, Anil AC, Sawant SS. 2014. Interactions of bacteria with diatoms: Influence on natural marine biofilms. Marine Ecology 35:233-248.

Khandeparker L, Anil AC, Naik SD, Gaonkar CC. 2015. Daily variations in pathogenic bacterial populations in a monsoon influenced tropical environment. Marine Pollution Bulletin 96:337-343.

Khandeparker L, Eswaran R, Gardade L, Kuchi N, Mapari K, Naik SD, Anil AC. 2017a. Elucidation of the tidal influence on bacterial populations in a monsoon influenced estuary through simultaneous observations. Environmental Monitoring and Assessment 189(41):1-17.

Khandeparker L, Kuchi N, Kale D, Anil AC. 2017b. Microbial community structure of surface sediments from a tropical estuarine environment using next generation sequencing. Ecological Indicators 74:172-181.

Kim BH, Lee MK. 2012. A case of bacteremia due to Microbacterium oleivorans identified by $16 \mathrm{~S}$ rRNA sequencing analysis. Korean Journal of Clinical Microbiology 15(3):110-113.

Li X, Qin L. 2005. Metagenomics-based drug discovery and marine microbial diversity. Trends in Biotechnology 23(11):539-543.

López-Amorós R, Castel S. Comas-Riu J, Vives-Rego J. 1997. Assessment of E. coli and Salmonella viability and starvation by confocal laser microscopy and flow cytometry using rhodamine 123, DiBAC4 (3), propidium iodide, and CTC. Cytometry 29(4):298-305.

Lyon WJ. 2001. TaqMan PCR for Detection of Vibrio cholerae O1, O139, Non-O1, and Non-O139 in pure cultures, raw oysters, and synthetic seawater. Applied and Environmental Microbiology 67(10):4685-4693.

Maskey RP, Li FC, Qin S, Heinz HF, Laatsch H. 2003. Chandrananimycins A-C: Production of novel anticancer antibiotics from a marine Actinomadura sp. isolate M048 by variation of medium composition and growth conditions. Journal of Antibiotics 56:622-629.

McCallum HI, Kuris A, Harvell CD, Lafferty KD, Smith GW, Porter J. 2004. Does terrestrial epidemiology apply to marine systems? Trends in Ecology and Evolution 19(11):585-591.

Mimura H, Katakura R, Ishida H. 2005. Changes of microbial populations in a ship's ballast water and sediments on a voyage from Japan to Qatar. Marine Pollution Bulletin 50(7):751-757.

Moriarty DJW. 1998. Control of luminous Vibrio species in penaeid aquaculture ponds. Aquaculture 164(14):351-358.

Mourino-Pérez RR, Worden AZ, Azam F. 2003. Growth of Vibrio cholerae $\mathrm{O} 1$ in red tide waters off California. Applied and Environmental Microbiology 69:6923-6931.

Not F, Simon N, Biegala IC, Vaulot D. 2002. Application of fluorescent in situ hybridization coupled with tyramide signal amplification (FISH-TSA) to assess eukaryotic picoplankton composition. Aquatic Microbial Ecology 28(2):157-166.

Oren A. 2004. Prokaryote diversity and taxonomy: current status and future challenges. Philosophical Transactions of the Royal Society of London 359:623-638.

Philippine Ports Authority. 2015. Ports services handbook: South Harbour. Manila: Philippine Ports Authority.

Rehnstam-Holm A -S, Godhe A, Härnström K, Raghunath P, Saravanan V, Collin B, Karunasagar I, Karunasagar I. 2010. Association between phytoplankton and Vibrio spp. along the southwest coast of India: a mesocosm experiment. Aquatic Microbial Ecology 58:127-139.

Roszak DB, Grimes DJ, Colwell RR. 1984. Viable but nonrecoverable stage of Salmonella enteritidis in aquatic systems. Canadian Journal of Microbiology 30(3):334-338.

Ruiz GM, Rawlings TK, Dobbs FC, Drake LA, Mullady T, Huq A, Colwell RR. 2000. Global spread of microorganisms by ships. Nature 408(6808):49-50.

Sack RB, Siddique AK, Longini IM, Nizam A, Yunus M, Islam MS, Morris JG, Ali A, Huq A, Nair B, Qadri F, Faruque SH, Sack DA, Colwell RR. 2003. A 4-year study of the epidemiology of Vibrio cholerae in four rural areas of Bangladesh. Journal of Infectious Diseases 187(1):96-101.

Schoemar S, Yanagi T. 2001. Seasonal variation of water characteristics in the northern coastal area of Java. La mer 39:77-85.

Shvalov AN, Soini JT, Surovtsev IV, Kochneva GV, Sivolobova GF, Petrov AK, Maltsev VP. 2000. ndividual Escherichia coli cells studied from light scattering with the scanning flow cytometer. Cytometry 41(1):41-45.

Sims D, Brettin T, Detter JC, Han C, Lapidus A, Copeland A, Del Rio TG, Nolan M, Chen F, Lucas S, Hope T, Cheng J-F, Bruce D, Goodwin L, Pitluck S, Ovchinnikova G, Pati A, Ivanova N, Mavromatis K, Chen A, Palaniappan K, D'haeseleer P, Chain P, Bristow J, Eisen JA, Markowitz V, Hugenholtz P, Schneider S, Göker M, Pukall R, Kyrpides NC, Klenk H-P. 2009. Complete genome sequence of Kytococcus sedentarius type strain (541T). Standards in Genomic Science 1:12-20.

Siregar TH, Priyanto N, Putri AK, Rachmawati N, Triwibowo 
R, Dsikowitzky L, Schwarzbauer J. 2016. Spatial distribution and seasonal variation of the trace hazardous element contamination in Jakarta Bay, Indonesia. Marine Pollution Bulletin 110(2):634-646.

Smith LD, Wonham MJ, McCann LD, Reid DM, Carlton JT, Ruiz GM. 1996. Biological invasions by nonindigenous species in United States waters: quantifying the role of ballast water and sediments. Parts I and II. The National Biological Invasions Shipping Study II (NABISS II) US Coast Guard and the US Department of Transportation, Washington DC (Rep. No. CG-D02-97, Gov. Access. No. ADA321543).

Sugita H, Hirose Y, Matsuo N, Deguchi Y. 1998. Production of the antibacterial substance by Bacillus sp. strain NM 12, an intestinal bacterium of Japanese coastal fish. Aquaculture 165(3-4):269-280.

Sun B, Mouland R, Way C, Rivkin RB. 2010. Redistribution of heterotrophic prokaryotes through ballast water: a case study from the west coast of Canada. Aquatic Invasions 5(1):5-11.

Tang KW. 2005. Copepods as microbial hotspots in the ocean: effects of host feeding activities on attached bacteria. Aquatic Microbial Ecology 38:31-40.

Troussellier M, Courties C, Zettelmaier S. 1995. Flow cytometric analysis of coastal lagoon bacterioplankton and picophytoplankton: fixation and storage effects. Estuarine, Coastal and Shelf Science 40(6):621-633.

Tsukamura M. 1971. Proposal of a new genus, Gordonia, for slightly acid-fast organisms occurring in sputa of patients with pulmonary disease and in soil. Journal of General Microbiology 68:15-26.

Williams RJ, Griffiths FB, Van der Wal EJ, Kelly J. 1988. Cargo vessel ballast water as a vector for the transport of non-indigenous marine species. Estuarine, Coastal and Shelf Science 26(4):409-420. 
